\title{
Learning-Induced arg 3.1/arc mRNA Expression in the Mouse Brain
}

\author{
Monique Montag-Sallaz ${ }^{1}$ and Dirk Montag \\ Neurogenetics Research Group, Leibniz Institute for Neurobiology, D-39118 Magdeburg, Germany
}

\begin{abstract}
The effector immediate-early gene (IEG) arg 3.1, also called arc, encodes a protein interacting with the neuronal cytoskeleton. The selective localization of arg 3.1/arc mRNA in activated dendritic segments suggests that the arg 3.1/arc protein may be synthesized at activated post-synaptic sites and that arg 3.1/arc could participate in structural and functional modifications underlying cognitive processes like memory formation. To analyze whether learning itself is sufficient to trigger expression of arg 3.1/arc, we developed a one-trial learning paradigm in which mice learned to enter a dark compartment to escape from an aversively illuminated area. Arg 3.1/arc mRNA expression was analyzed by in situ hybridization in three groups of mice as follows: a control group with no access to the dark compartment, a learning group having access to the dark compartment for one trial, and a retrieval group having access to the dark compartment for two trials on consecutive days. All animals from the learning and retrieval groups escaped the illuminated area, and those tested $24 \mathrm{~h}$ later (retrieval group) showed a strongly reduced latency to enter the dark compartment, demonstrating the validity of our learning paradigm to induce long-term memory. Our results show that acquisition of a simple task results in a brain area-specific biphasic increase in arg 3.1/arc mRNA expression $15 \mathrm{~min}$ and $4.5 \mathrm{~h}$ post-training. This increase was detected specifically in the learning group but neither in the control nor in the retrieval groups. The pattern of arg 3.1/arc mRNA expression corresponds temporally to the two mRNA- and protein-synthesis-dependent periods of long-term memory formation. Our study provides the first unequivocal evidence that arg 3.1/arc expression is induced by a learning task and strongly suggests a role of arg 3.1/arc mRNA in the early and late cellular mechanisms underlying the stabilization of the memory trace.
\end{abstract}

Long-term memory is supported by a cascade of cellular events including protein synthesis, changes in the molecular composition and the structure of existing synapses, and formation of new synaptic contacts (for review, see DiAntonio 2000; Mc Gaugh 2000). This synaptic plasticity is likely to involve molecules associated with the cytoskeleton (Matus 2000; Huntley et al. 2002). The protein encoded by the effector IEG activity-regulated gene 3.1 (arg 3.1; Link et al. 1995), also activity-regulated cytoskeleton-associated protein (arc; Lyford et al. 1995), is related distantly to $\alpha$-spectrin, coprecipitates with F-actin (Link et al. 1995; Lyford et al. 1995), concentrates in postsynaptic densities, and is associated with NMDA receptors (Steward and Worley 2001). Furthermore, newly synthesized arg 3.1/arc mRNA is selectively localized in activated dendritic segments (Steward et al. 1998: Wallace et al. 1998), suggesting that the Arg $3.1 /$ arc protein may be synthesized specifically at activated postsynaptic sites after the appropriate stimulation (Steward and Worley 2001). This postulated synapse-specific protein synthesis might be involved directly in structural and functional modifications leading to neuronal plasticity underlying cognitive processes like memory formation (Schu-

${ }^{1}$ Corresponding author.

E-MAIL sallaz@ifn-magdeburg.de; FAX 49-391-6263252.

Article and publication are at http://www.learnmem.org/cgi/doi/ $10.1101 / \mathrm{lm} .53403$. man 1999; Wells et al. 2000; Steward and Schuman 2001). In agreement with this hypothesis, arg 3.1/arc expression is altered by several experimental paradigms known to induce synaptic plasticity as high-frequency stimulation of the perforant path inducing long-term potentiation (LTP) (Link et al. 1995; Lyford et al. 1995), presentation of a novel stimulus (Guzowski et al. 1999; Montag-Sallaz et al. 1999; Guthrie et al. 2000; Montag-Sallaz and Buonviso 2002), and exposure to an enriched environment (Pinaud et al. 2001). In addition, disruption of Arg 3.1/arc protein expression by intrahippocampal infusion of antisense oligodeoxynucleotides impairs the maintenance phase of LTP without affecting its induction, and impairs consolidation of long-term memory for a spatial water-task training without affecting task acquisition or short-term memory (Guzowski et al. 2000). In summary, arg 3.1/arc expression appears to play a fundamental role in the stabilization of the activity-dependent synaptic plasticity and may be crucial for the formation of long-term memory. The recent studies by Guzowski et al. (2001) and Kelly and Deadwyler (2002) showing increased arg 3.1/arc expression after spatial and nonspatial learning, respectively, support this hypothesis. However, long-term memory formation depends on two waves of protein synthesis occurring $30 \mathrm{~min}$ and 4 to $5 \mathrm{~h}$ after training (Tiunova et al. 1998; Quevedo et al. 1999). Furthermore, mRNA synthesis during similar time periods is critical for the forma-

LEARNING \& MEMORY 10:99-107 @ 2003 by Cold Spring Harbor Laboratory Press ISSN1072-0502/03 \$5.00

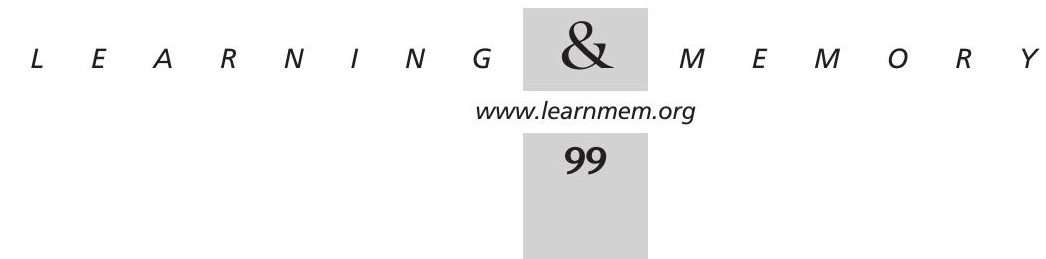


tion and the consolidation of long-term memory (Igaz et al. 2002). Previously, we demonstrated that presentation of a new gustatory stimulus induces two waves of increased arg 3.1/arc mRNA expression temporally matching these two critical periods (Montag-Sallaz et al. 1999). In previous studies, expression of arg 3.1/arc after spatial/nonspatial learning was not analyzed 4 to $5 \mathrm{~h}$ after learning. Furthermore, spatial learning in the water maze (Guzowski et al. 2001) and operant conditioning (Kelly and Deadwyler 2002) require multiple training sessions to acquire the task, which makes it difficult to determine precisely the onset of learning. In addition, nonhandled animals remaining in their home cage as controls for rats trained in the spatial and nonspatial versions of the water maze, as used by Guzowski et al. (2001), do not allow definitive statements on arg 3.1/ arc expression specific for memory formation, because arg $3.1 /$ arc expression can be induced by specific and nonspecific factors associated with the behavioral training procedure (Kelly and Deadwyler 2002). In summary, conclusive data are still missing to unequivocally relate arg 3.1/arc expression and formation of long-term memory.

This question can only be addressed by use of a paradigm fulfilling particular criteria. Stress resulting from the handling of the animals and the encounter of a novel potentially harmful environment has to be avoided or minimized, as both factors modify the expression of arg 3.1/arc (Guzowski et al. 1999; Pinaud et al. 2001). The timing of the learning onset has to be defined exactly to correlate changes in IEG expression with memory formation. Therefore, a single trial has to be sufficient for the animals to learn the task, and start and duration of the learning phase have to be monitored precisely. In addition, it is crucial that all animals learn the task, because IEG expression has to be detected in animals sacrificed after the learning trial, without any possibility to test the performance of the animal later. Finally, to prove that a change in IEG expression is learning specific, appropriate controls are required and must be possible with the chosen paradigm. On the basis of these requirements, we developed a one-trial learning paradigm in which the animals had to learn to enter a dark compartment to escape the aversive illuminated one (light/ dark box). Three habituation sessions were performed prior to the test to reduce the influence of nonspecific factors associated with the behavioral training on arg 3.1/arc expression. Expression of arg 3.1/arc mRNA was analyzed by in situ hybridization in selected brain areas of mice $15 \mathrm{~min}$, $1 \mathrm{~h}, 4.5 \mathrm{~h}$, and $6 \mathrm{~h}$ after learning the location of the dark compartment (learning group), and in mice with no access to this compartment (control group), or performing the test for a second time $24 \mathrm{~h}$ after the learning session (retrieval group).

\section{RESULTS}

To analyze whether learning and memory formation are accompanied by a specific change in arg 3.1/arc expression, a one-trial paradigm fulfilling particular criteria, as stress avoidance, strictly monitored learning onset, and the possibility to control the learning specificity of the change in arg $3.1 /$ arc expression is required. Therefore, we developed a one-trial learning paradigm in which the animals learned to enter a dark compartment to escape the aversive illuminated area of a light/dark box.

\section{Habituation of the Animals to the Light/Dark Box}

To reduce the influence of nonspecific factors associated with the behavioral training on arg 3.1/arc expression during the learning session (day 4), the animals were submitted to three habituation sessions on consecutive days 1 to 3 . The animals were placed in the middle of the illuminated compartment and allowed to visit this compartment for 10 min, but had no access to the dark compartment.

\section{Performance of the Animals in the Light/Dark Box}

During the learning trial (day 4), all animals of the learning and retrieval groups entered the dark compartment of the light/dark box with an average latency of 214.52s (Fig. 1), showing that for all of them, motivation was high enough to perform the task during the 10-min trial duration without any need of additional punishment or reward.

On day 5, the latency to enter the dark compartment was dramatically reduced for the retrieval group [69.3s; $67.70 \%$ shorter; $\mathrm{F}_{(1,27)}=14.099 ; P=0.0008$; Fig. 1$]$ and for each single mouse of the group (data not shown). These results clearly demonstrate that a single 10 -min trial is sufficient for mice to learn to enter the dark compartment of the arena and to remember this $24 \mathrm{~h}$ later. Acquisition of the task cannot be verified in the animals of the learning group sacrificed after the learning session, however, the performance of the retrieval animals strongly indicates that the task is acquired by all mice during the 10-min learning trial. In addition, the beginning and duration of the acquisition period are perfectly controlled. This one-trial learning paradigm fulfills the required criteria as stress avoidance, acquisition within one trial, $100 \%$ performance of the mice, exact monitoring of the time of learning onset, and the possibility to control the learning specificity of the change in arg 3.1/ arc expression. Therefore, this test fulfills all criteria for the analysis of arg 3.1/arc expression during long-term memory formation.

\section{Arg 3.1/arc mRNA Expression}

Without induction, the level of arg 3.1/arc expression detected by nonradioactive in situ hybridization is relatively low in most brain areas. Therefore, the dentate gyrus was used as a control area, in which a small number of strongly labeled cells can always be detected (see Fig. 2), allowing the exclusion of any possible technical problems.

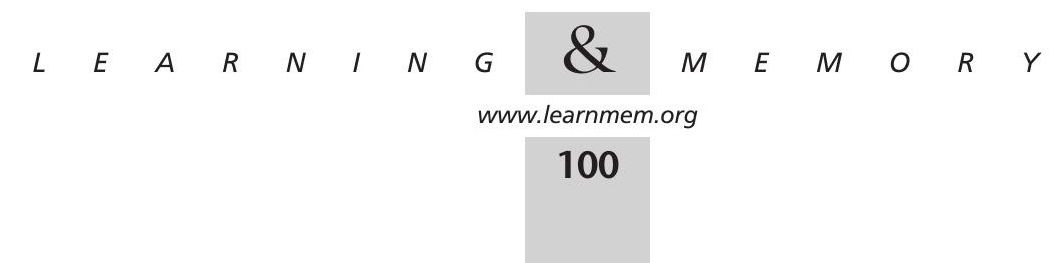



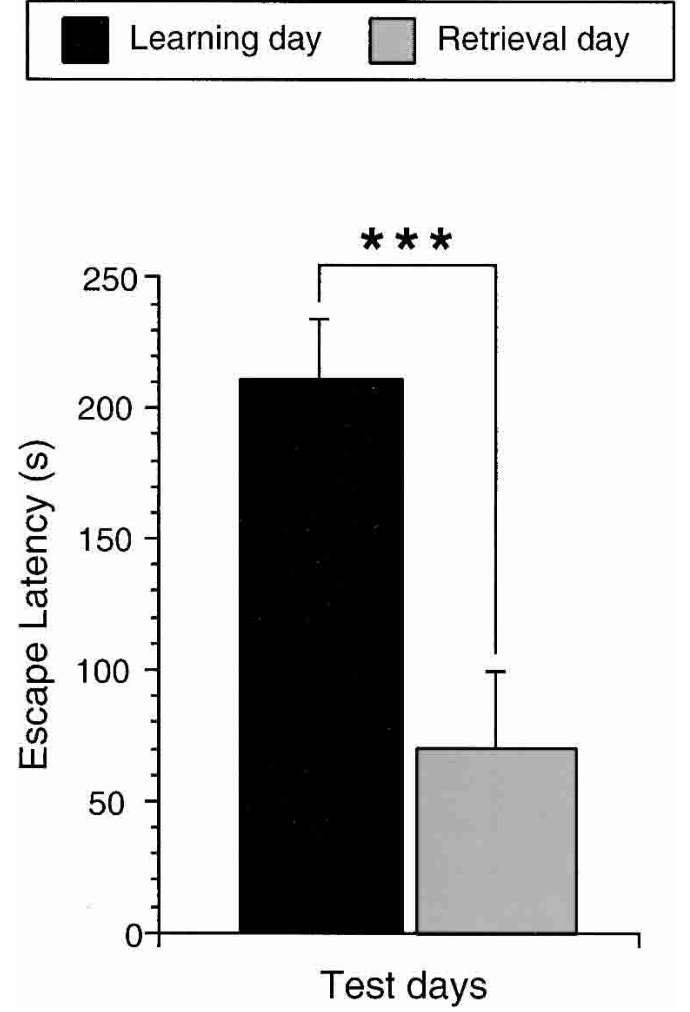

Figure 1 Performance of the learning and retrieval group animals in the light/dark box learning paradigm. Bar graphs illustrating the average latency of the animals of the learning and retrieval groups to enter the dark compartment. The latencies were strongly reduced from the first to the second test day. (Learning day) A total of 19 animals were analyzed; (retrieval day) 10 animals were analyzed. $\left.{ }^{* * *}\right) P<0.001$

Hybridization with the digoxigenin-labeled probe revealed that arg 3.1/arc mRNA expression was elevated strongly in several brain areas of the learning animals compared with control and retrieval groups $15 \mathrm{~min}$ and/or $4.5 \mathrm{~h}$ after the test (illustrated in Fig. 2 for the anterior cingulate cortex of learning animals compared with controls). Animals from the control (Fig. 2) and retrieval (data not shown) groups showed a similar lower number of labeled cells at each time point. In addition, for the animals of the control and retrieval groups, arg 3.1/arc mRNA expression at the 4.5-h time point was similar to expression at the 1- and 6-h time points, and only slightly elevated $15 \mathrm{~min}$ after the session compared with the other three time points. These results indicate that learning increased arg 3.1/arc expression at two distinct time points, $15 \mathrm{~min}$ and/or $4.5 \mathrm{~h}$ after stimulation.

For quantitative analysis of the learning-induced change in arg 3.1/arc expression, in situ hybridization using a ${ }^{35}$ S-labeled probe was performed. On the basis of the results obtained with the digoxigenin-labeled probe, we focused on the 15-min and 4.5-h time points and on the fol- lowing brain areas: the glomerular and granular cell layers of the olfactory bulb, the anterior and posterior cingulate cortex, CA1, CA2-CA3, and dentate gyrus of the hippocampus, the piriform cortex, the amygdala, layers I-IV, V, and VI of the parietal, the sensory, and the motor cortices. As shown in Figure 3, in situ hybridization with the ${ }^{35}$ S-labeled probe revealed that the expression of arg 3.1/arc mRNA was higher in the learning group than in the control and retrieval groups $15 \mathrm{~min}$ and $4.5 \mathrm{~h}$ after the session. For all three groups, arg 3.1/arc expression was lower at the 4.5-h time point compared with $15 \mathrm{~min}$. The relative optical densities were determined for each brain area and compared between the different animal groups (Fig. 4) using a 2-way ANOVA with time of sacrifice after the test (15 min and 4.5 h), and stimulation used (control, learning, and retrieval) as factors, unless otherwise indicated (for $\mathrm{F}$ and $P$ values, see Table 1). The statistical analysis confirmed that arg 3.1/arc expression was higher at 15 min than $4.5 \mathrm{~h}$ post-training (time effect) in the olfactory bulb (glomerular and granule cell layers), the anterior and posterior cingulate cortex, CA1 of the hippocampus, all layers of the parietal cortex, and layer VI of the motor cortex. In addition, arg 3.1/arc expression in several brain areas was dependent on the experimental conditions (stimulation effect) and increased in the learning group compared with control and retrieval groups. This learning effect was detected in the granular cell layer of the olfactory bulb, the anterior and posterior cingulate cortex, the piriform cortex, CA1, CA2-CA3, and dentate gyrus of the hippocampus, layers I-IV and VI of the parietal cortex, layers I-IV and V of the motor cortex, and layers I-IV and V of the sensory cortex. The changes in arg 3.1/arc expression induced by each experimental condition (learning, control, or retrieval) significantly differed depending on the time of sacrifice (interaction between stimulation and time) in the glomerular layer of the olfactory bulb, CA2-CA3 and dentate gyrus of the hippocampus, layer VI of the parietal cortex, layers I-IV of the motor cortex, and layers I-IV, V, and VI of the sensory cortex. In the anterior cingulate cortex and layers I-IV and VI of the parietal cortex, arg 3.1/arc showed a peak of expression at the 15-min and 4.5-h time points in the learning group compared with the control and retrieval groups (Fig. 4A-C). A similar biphasic pattern of arg 3.1/arc expression was detected in the posterior cingulate cortex, piriform cortex, and hippocampus proper (CA1, CA2-CA3), but the difference between learning and control/retrieval animals reached significance only at the 4.5-h time point (Fig. 4D$\mathrm{G})$. In the amygdala, dentate gyrus, layer $\mathrm{V}$ of the parietal cortex, and all layers of the sensory and motor cortices (data not shown), arg 3.1/arc showed a peak of expression in the learning group only at the 4.5 -h time point (Fig. 4 $\mathrm{H}-\mathrm{J})$. The granule cell layer of the olfactory bulb showed a learning-related arg 3.1/arc peak of expression only at the 15 -min time point (Fig. $4 \mathrm{~K}$ ). Finally, in the glomerular

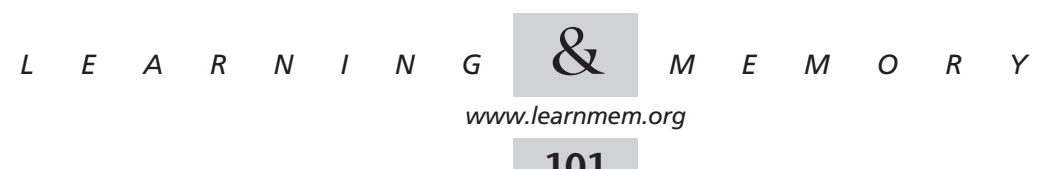


$15 \min$
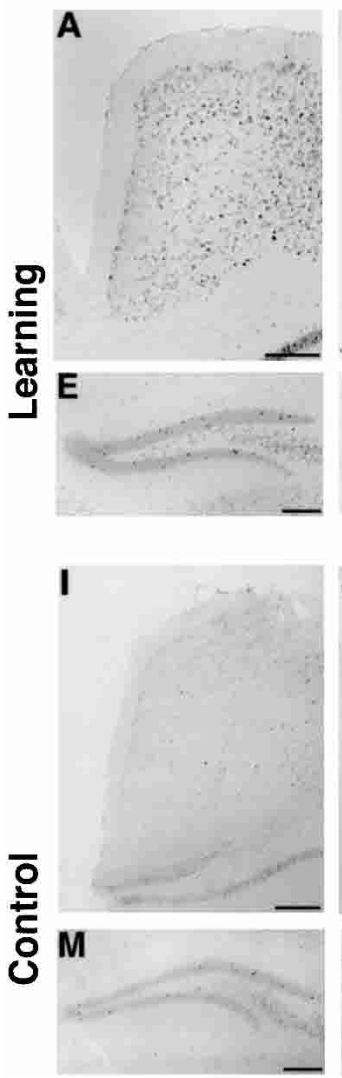

$1 \mathrm{~h}$
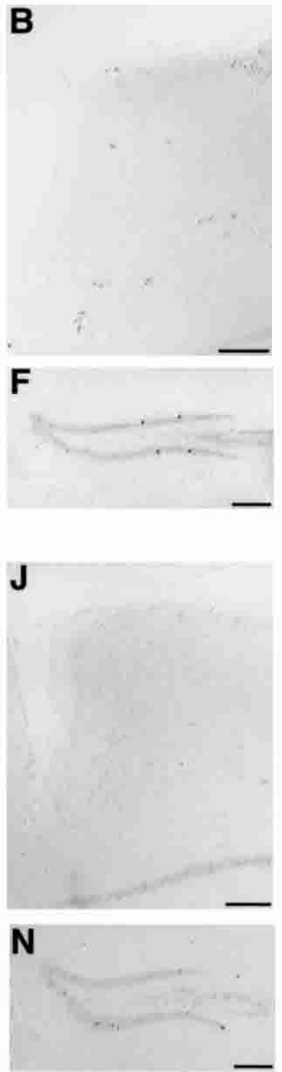

$4.5 \mathrm{~h}$
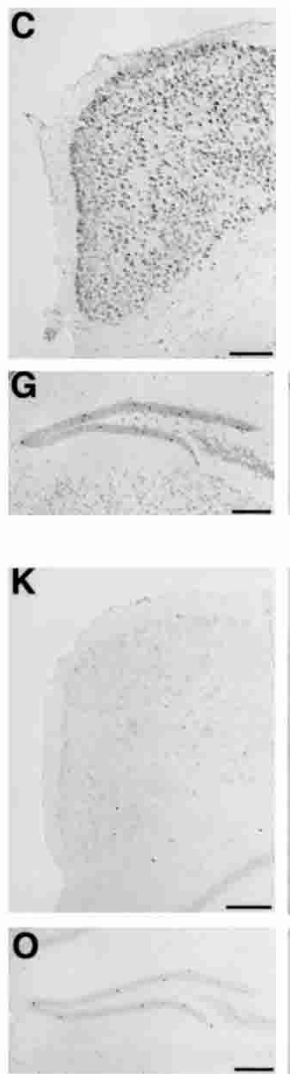

Figure 2 arg 3.1/arc mRNA expression in the cingulate cortex and dentate gyrus detected by non-radioactive in situ hybridization. Frontal sections showing arg 3.1/arc mRNA expression detected by in situ hybridization using a digoxigenin-labeled antisense probe in the cingulate cortex $(A-D, I-L)$ and the dentate gyrus $(E-H, M-P)$ of mice from the learning $(A-H)$ or control $(I-P)$ groups sacrificed $15 \mathrm{~min}(A, E, I, M), 1 \mathrm{~h}(B, F, J, \mathrm{~N}), 4.5 \mathrm{~h}(C, G, K, O)$, and $6 \mathrm{~h}(D, H, L, P)$ after the test. Two peaks of arg 3.1 expression in the cingulate cortex are clearly visible for the animals of the learning group at the 15-min and 4.5-h time points. In the dentate gyrus, some strongly labeled cells are always visible, and were used as control for the reaction. Scale bars, $200 \mu \mathrm{m}$.

layer of the olfactory bulb, no learning-induced increase of arg 3.1/arc mRNA expression could be detected. Arg 3.1/ arc mRNA expression did not differ significantly between the retrieval and the control groups at both time points (Fig. 4), except in layer VI of the parietal cortex $15 \mathrm{~min}$ after the test, in which arg 3.1/arc mRNA expression was significantly higher in the retrieval compared with the control group.

\section{DISCUSSION}

\section{Validity of the One-Trial Learning Paradigm}

In this study, we examined the hypothesis that arg 3.1/arc may be expressed specifically in a context of learning and memory formation, and that the acquisition of a task, as a natural occurring stimulus, may suffice to induce arg 3.1/arc expression. Therefore, we developed a one-trial learning

$6 \mathrm{~h}$
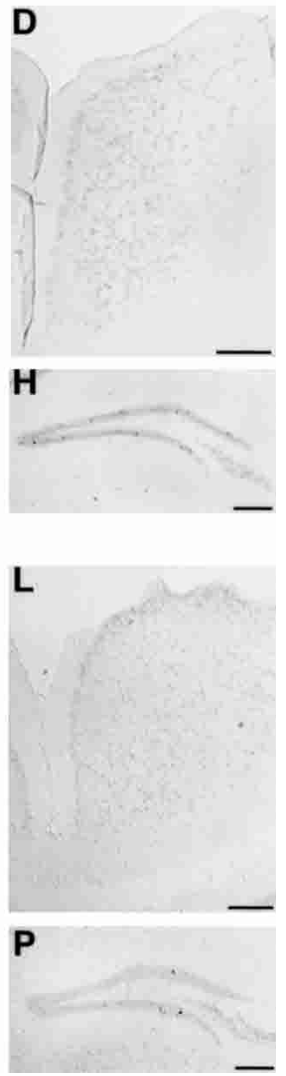

paradigm in which the animals had to learn to enter a dark compartment to escape from an aversive illuminated area. This test design presents several advantages. Habituation to the test situation for $3 \mathrm{~d}$ strongly reduces stress resulting from the handling of the animals and the encounter of a novel, potentially harmful environment. This is crucial for the analysis of arg 3.1/arc expression, as both factors modify its expression (Guzowski et al. 1999; Pinaud et al. 2001; Kelly and Deadwyler 2002). Furthermore, a one-trial learning paradigm is best suited when monitoring IEG expression at the mRNA level by in situ hybridization, because of the short half life of the IEGs mRNA (Steward and Worley 2001). If several trials are required by the animal to learn a task, the exact time of learning and memory formation cannot be assessed precisely. In addition, in our paradigm, all animals learned to enter the dark compartment during the learning session and remembered this $24 \mathrm{~h}$ later, showing that animals are motivated to perform the task and to learn the location of the preferred area. One hundred percent performance is necessary if learning cannot be confirmed for each animal (learning group). Therefore, our one-trial learning paradigm is particularly useful to study the potential changes in IEG expression related to learning and long-term memory formation.

\section{Arg 3.1/arc mRNA Expression Triggered by Exposure to the Training Paradigm}

In most of the brain areas studied, arg 3.1/arc mRNA expression was higher $15 \mathrm{~min}$ after the behavioral session than after $4.5 \mathrm{~h}$ independently of the task the animals performed. In addition, for the control and retrieval groups, the level of arg 3.1/arc expression detected at the 15-min time point was elevated compared with the three other time points, which did not differ from each other (Fig. 2). These results strongly suggest that the increase in arg 3.1/arc mRNA expression detected early after a training session in the learning group depends, in part, on nonspe-

$$
\begin{array}{lllllllllllllll}
\text { L } & E & A & R & N & I & N & G & \mathcal{Z} & M & E & M & O & R & Y \\
\text { www.learnmem.org } & & &
\end{array}
$$


$15 \mathrm{~min}$.
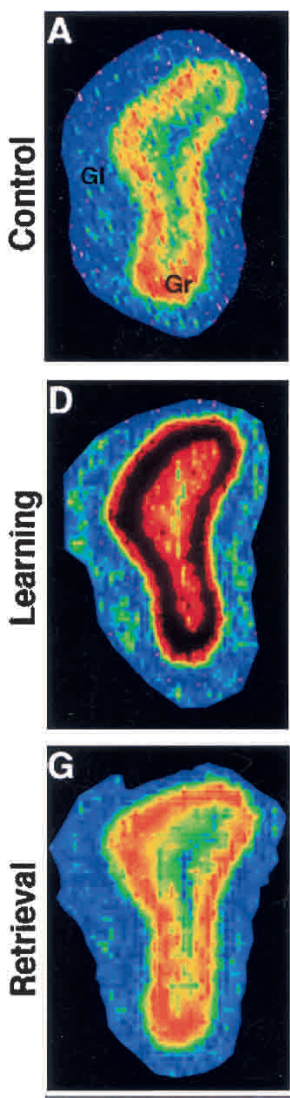
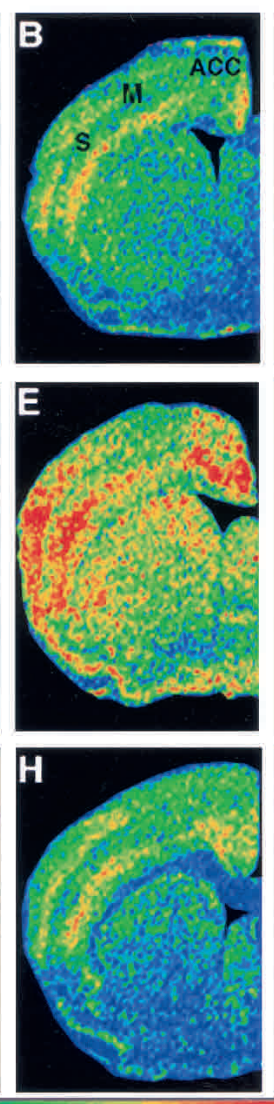

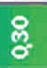
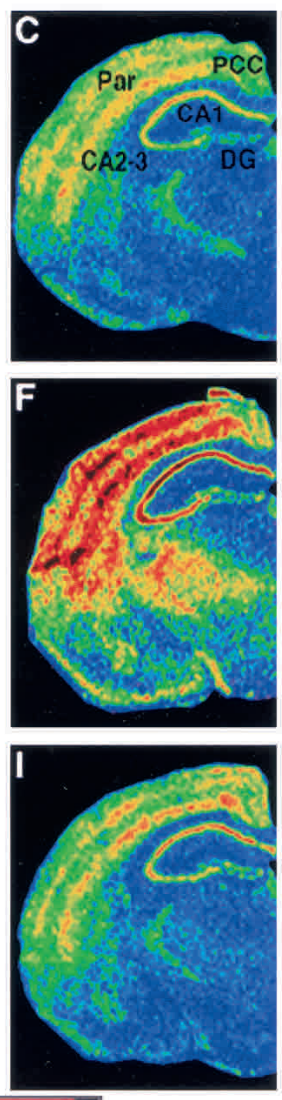

$\underset{\Sigma}{E}$ 4.5h
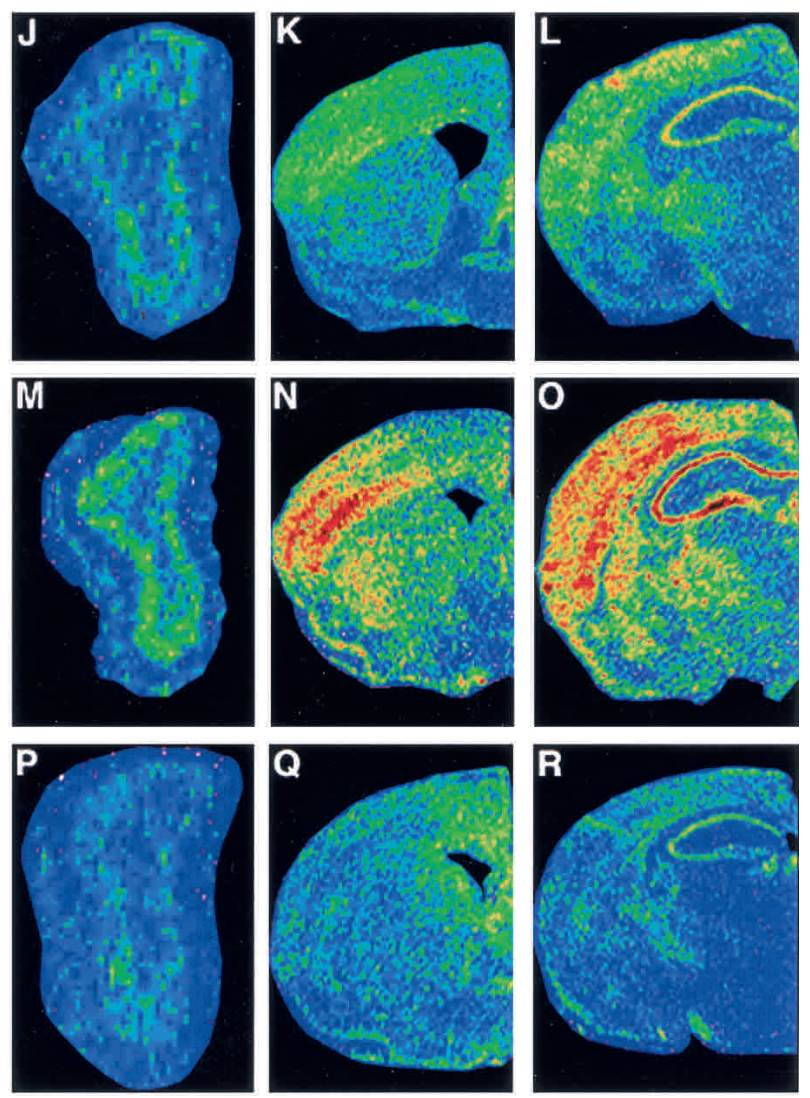

Figure 3 arg 3.1/arc mRNA expression in different brain areas detected by radioactive in situ hybridization. Pseudocolor images of film autoradiograms showing densities of arg 3.1/arc expression detected in different brain areas by in situ hybridization using a ${ }^{35} \mathrm{~S}$-labeled antisense probe. Control $(A-C)$, learning $(D-F)$, and retrieval $(G-l)$ animals sacrificed 15 min after the test; control $(J-L)$, learning $(M-O)$ and retrieval $(P-R)$ animals sacrificed $4.5 \mathrm{~h}$ after the test. Note the increased expression of arg $3.1 /$ arc at $15 \mathrm{~min}$ compared with $4.5 \mathrm{~h}$ post-training in the three experimental groups, and in the learning group compared with the control and retrieval groups 15 min and $4.5 \mathrm{~h}$ after the session. (Gl) Glomerular layer of the olfactory bulb; (Gr) granule cell layer of the olfactory bulb; (ACC) anterior cingulate cortex; (M) motor cortex; (S) sensory cortex; (PCC) posterior cingulate cortex; (Par) parietal cortex; (CA1) CA1 subfield of the hippocampus; (CA): CA3 subfield of the hippocampus ; (DG) dentate gyrus of the hippocampus; (Pir) piriform cortex; (A) amygdala. Scale bars, $260 \mu \mathrm{m}(A, D, G, J, M, P), 1370 \mu \mathrm{m}$ $(B, E, H, K, N, Q), 1060 \mu \mathrm{m}(C, F, I, L, O, R)$.

cific factors related to the behavioral training procedure. This is supported by the recent study of Kelly and Deadwyler (2002), who found similar results using a leverpressing operant conditioning paradigm. In contrast, the later wave of arg 3.1/arc mRNA expression we detected only in the learning group $4.5 \mathrm{~h}$ after the training session is more specifically correlated with the mechanisms underlying memory formation than elevated arg 3.1/arc mRNA expression detected at the 15-min time point. However, the higher level of arg 3.1/arc mRNA expression in the learning group compared with control and retrieval groups 15 min after training indicates that mechanisms specific to memory formation are also likely to occur at this early stage.

\section{Arg 3.1/arc mRNA Expression After a One-Trial Learning Paradigm}

Learning to enter the dark compartment in the light/dark box resulted in increased arg 3.1/arc mRNA expression in several cortical and limbic areas of the mouse brain $15 \mathrm{~min}$ and/or $4.5 \mathrm{~h}$ later, particularly in the cingulate, parietal, and piriform cortices, and in the hippocampus and amygdala. This effect was specific for the learning group and was not detected in control animals submitted to the same test, but without access to the dark compartment, or in retrieval animals sacrificed after performing the test a second time 24 $\mathrm{h}$ after learning. Therefore, the possibility that the observed differences in arg 3.1/arc mRNA expression between learning and control/retrieval groups could be induced by the

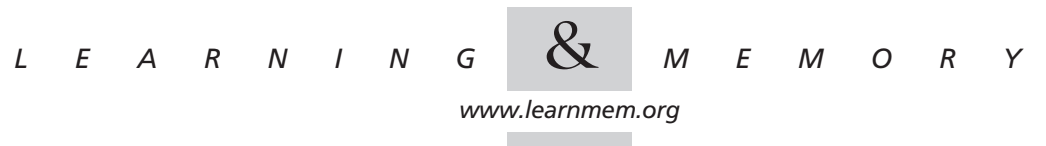




\begin{tabular}{|l|}
$\square$ Control \\
$\square$ Learning \\
$\square$ Retrieval \\
\hline
\end{tabular}

C

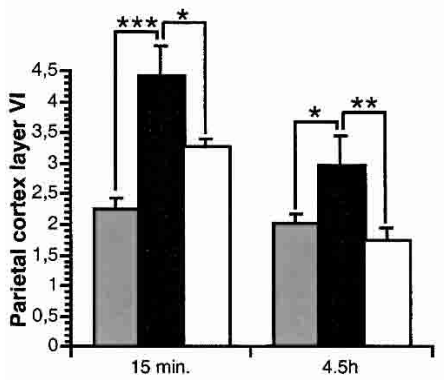

F

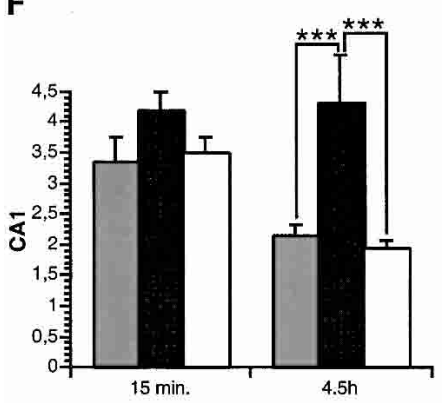

I

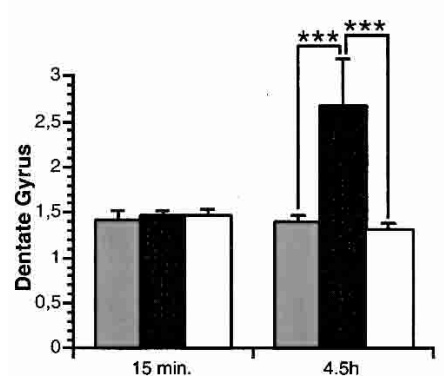

A

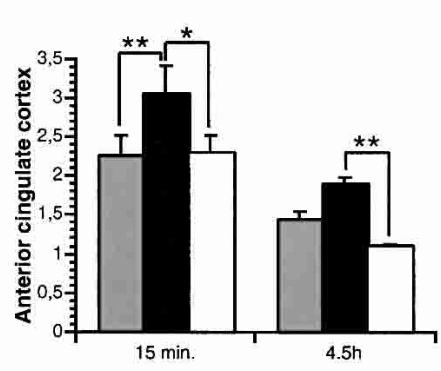

D

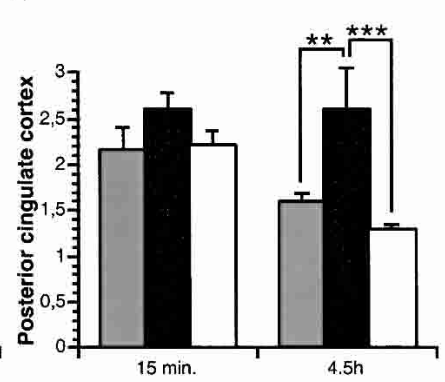

G

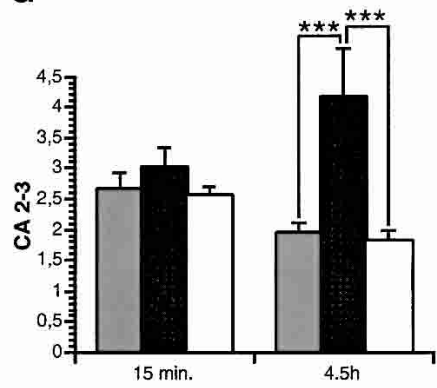

J

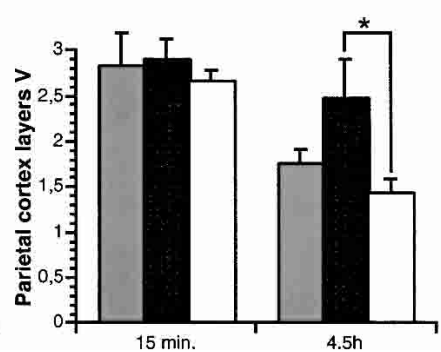

B

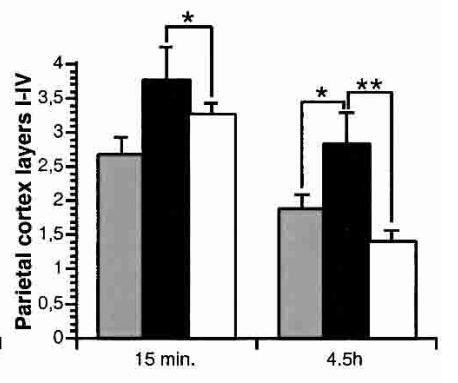

E

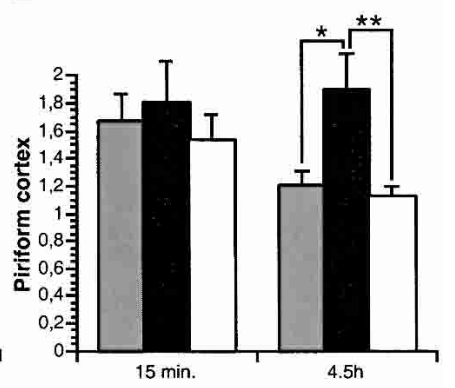

H

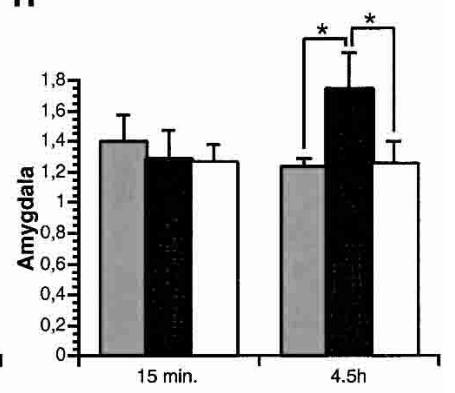

K

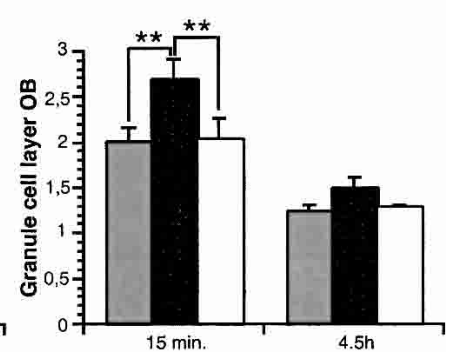

Figure 4 Quantification of arg 3.1/arc mRNA expression detected by radioactive in situ hybridization. Bar graphs illustrating the average relative optical density (+/- SEM) measured in several brain areas. Note the learning-induced peaks of arg 3.1/arc mRNA expression 15 min and $4.5 \mathrm{~h}$ post-training in the anterior cingulate cortex $(A)$ and layers I-IV $(B)$, and $\mathrm{VI}(C)$ of the parietal cortex, only at the 4.5-h time point in the posterior cingulate cortex $(D)$, piriform cortex $(E)$, hippocampus CA1 $(F)$, CA2-CA3 $(G)$, amygdala $(H)$, dentate gyrus $(I)$, layer $\mathrm{V}$ of the parietal cortex $(/)$, and only 15 min post-training in the granule cell layer of the olfactory bulb $(K) .(*) P<0.05 ;(* *) P<0.01 ;(* * *) P<0.001$.

activity of the mice or factors other than the learning conditions can be excluded.

Interestingly, the temporal pattern of arg 3.1/arc expression appears to be brain area specific. These brain area- dependent changes in arg 3.1/arc mRNA are likely to reflect a specific role of these structures in the processing and storage of information and a function of arg 3.1/arc in these cognitive processes. It would have been interesting to com-

$$
\begin{array}{llllllllllllll}
\text { www.learnmem.org } & & & & & & & & & & & &
\end{array}
$$


Table 1. Statistical Analysis of arg 3.1/arc Expression Detected by Radioactive In Situ Hybridization

\begin{tabular}{|c|c|c|c|}
\hline Brain areas & Time & Stimulation & Interaction \\
\hline $\begin{array}{l}\text { Glomerular layer } \\
\text { olfactory bulb }\end{array}$ & $\begin{array}{l}F_{(1,48)}=62.3 \\
P<0.0001\end{array}$ & $\begin{array}{l}\mathrm{F}_{(2,48)}=3.391 \\
P=0.0419\end{array}$ & $\begin{array}{l}F_{(2,48)}=3.928 \\
P=0.0263\end{array}$ \\
\hline $\begin{array}{l}\text { Granular layer } \\
\text { olfactory bulb }\end{array}$ & $\begin{array}{l}F_{(1,48)}=42.78 \\
P<0.0001\end{array}$ & $\begin{array}{l}\mathrm{F}_{(2,48)}=4.908 \\
P=0.0115\end{array}$ & ns \\
\hline $\begin{array}{l}\text { Ant cingulate } \\
\text { cortex }\end{array}$ & $\begin{array}{l}\mathrm{F}_{(1,54)}=40.18 \\
P<0.0001\end{array}$ & $\begin{array}{l}\mathrm{F}_{(2,54)}=7.566 \\
P=0.0013\end{array}$ & ns \\
\hline Piriform cortex & ns & $\begin{array}{l}\mathrm{F}_{(2,54)}=3.80 \\
P=0.0285\end{array}$ & ns \\
\hline $\begin{array}{l}\text { Post cingulate } \\
\text { cortex }\end{array}$ & $\begin{array}{l}\mathrm{F}_{(1,54)}=6.68 \\
P=0.0125\end{array}$ & $\begin{array}{l}F_{(2,54)}=7.187 \\
P=0.0017\end{array}$ & ns \\
\hline $\begin{array}{l}\text { CA1 } \\
\text { hippocampus }\end{array}$ & $\begin{array}{l}F_{(1,54)}=6.4 \\
P=0.0143\end{array}$ & $\begin{array}{l}\mathrm{F}_{(2,54)}=8.14 \\
P=0.0008\end{array}$ & ns \\
\hline $\begin{array}{l}\text { CA2-3 } \\
\text { hippocampus }\end{array}$ & ns & $\begin{array}{l}\mathrm{F}_{(2,54)}=8.22 \\
P=0.0008\end{array}$ & $\begin{array}{l}F_{(2,54)}=3.958 \\
P=0.0249\end{array}$ \\
\hline $\begin{array}{l}\text { Dentate gyrus } \\
\text { hippocampus }\end{array}$ & ns & $\begin{array}{l}F_{(2,54)}=6.37 \\
P=0.0033\end{array}$ & $\begin{array}{l}\mathrm{F}_{(2,54)}=5.834 \\
P=0.0051\end{array}$ \\
\hline $\begin{array}{l}\text { Parietal cortex } \\
\text { layers I-IV }\end{array}$ & $\begin{array}{l}\mathrm{F}_{(1,54)}=24.118 \\
P<0.0001\end{array}$ & $\begin{array}{l}\mathrm{F}_{(2,54)}=7.05 \\
P=0.0019\end{array}$ & ns \\
\hline $\begin{array}{l}\text { Parietal cortex } \\
\text { layer V }\end{array}$ & $\begin{array}{l}\mathrm{F}_{(1,54)}=15.733 \\
P=0.0002\end{array}$ & ns & ns \\
\hline $\begin{array}{l}\text { Parietal cortex } \\
\text { layer VI }\end{array}$ & $\begin{array}{l}\mathrm{F}_{(1,54)}=19.47 \\
P<0.0001\end{array}$ & $\begin{array}{l}F_{(2,54)}=14.447 \\
P<0.0001\end{array}$ & $\begin{array}{l}\mathrm{F}_{(2,54)}=3.223 \\
P=0.0476\end{array}$ \\
\hline Amygdala & ns & ns & ns \\
\hline $\begin{array}{l}\text { Motor cortex } \\
\text { layers I-IV }\end{array}$ & ns & $\begin{array}{l}F_{(2,54)}=5.462 \\
P=0.0069\end{array}$ & $\begin{array}{l}\mathrm{F}_{(2,54)}=3.54 \\
P=0.0359\end{array}$ \\
\hline $\begin{array}{l}\text { Motor cortex } \\
\text { layer } \mathrm{V}\end{array}$ & ns & $\begin{array}{l}F_{(2,54)}=4.476 \\
P=0.0159\end{array}$ & ns \\
\hline $\begin{array}{l}\text { Motor cortex } \\
\text { layer VI }\end{array}$ & $\begin{array}{l}\mathrm{F}_{(1,54)}=4.07 \\
P<0.0486\end{array}$ & ns & ns \\
\hline $\begin{array}{l}\text { Sensory cortex } \\
\text { layers I-IV }\end{array}$ & ns & $\begin{array}{l}\mathrm{F}_{(2,54)}=4.135 \\
P=0.0213\end{array}$ & $\begin{array}{l}\mathrm{F}_{(2,54)}=5.299 \\
P=0.0079\end{array}$ \\
\hline $\begin{array}{l}\text { Sensory cortex } \\
\text { layer V }\end{array}$ & ns & $\begin{array}{l}\mathrm{F}_{(2,54)}=4.321 \\
P=0.0182\end{array}$ & $\begin{array}{l}\mathrm{F}_{(2,54)}=6.206 \\
P=0.0037\end{array}$ \\
\hline $\begin{array}{l}\text { Sensory cortex } \\
\text { layer VI }\end{array}$ & ns & ns & $\begin{array}{l}\mathrm{F}_{(2,54)}=7.346 \\
P=0.0015\end{array}$ \\
\hline
\end{tabular}

Summary of $\mathrm{F}$ and $P$ values from 2-way ANOVA analysis of the relative optical densities obtained from the arg 3.1/arc radioactive in situ hybridization autoradiograms with time and stimulation as factors for the brain areas investigated.

pare our present results with those obtained by Guzowski et al. (2001) and Kelly and Deadwyler (2002). Unfortunately, these groups used learning paradigms requiring several trials or sessions, which makes it difficult to determine precisely the moment the animals learned the task. In addition, the 4.5-h time point was not investigated. However, in agreement with our present results, both studies suggested that the regulation of arg 3.1/arc expression after learning is brain area dependent.

The increase in arg 3.1/arc expression was only detected $15 \mathrm{~min}$ and $4.5 \mathrm{~h}$ after the learning session, but not at the 1- or 6-h time points, demonstrating a specific temporal pattern of arg 3.1/arc expression after learning. These results are in agreement with our previous work showing increased arg 3.1/arc mRNA expression in response to the novelty of a gustatory stimulus $30 \mathrm{~min}$ and $4.5 \mathrm{~h}$ after pre- sentation of the stimulus, and lower levels of expression at 1 and $6 \mathrm{~h}$ after the stimulus (Montag-Sallaz et al. 1999). Interestingly, the two waves of increased arg 3.1/arc mRNA expression detected after the onetrial spatial learning paradigm temporally match the two time periods of mRNA and protein synthesis required for the formation and consolidation of longterm memory (for review, see Igaz et al. 2002). It is therefore tempting to speculate that arg 3.1/arc, like other effector genes, may play a critical role in memory formation during these two sensitive periods. Furthermore, as discussed by Kelly and Deadwyler (2002), the temporally restricted pattern of arg 3.1/arc expression is likely to have important functional implications. Arg 3.1/arc mRNA and protein are targeted to synapses that have experienced particular patterns of activity after stimulation or behavioral experience leading to long-lasting synaptic modifications (LTP, learning). Arg 3.1/arc protein, as a cytoskeleton-associated protein, is well suited to participate in molecular synaptic changes believed to underlie long-term synaptic plasticity. The specific functions of the Arg 3.1/arc protein may only be required during limited time windows post-training, which may be regulated by the amount of mRNA available for translation. Therefore, the temporal restriction of arg 3.1/arc expression could be crucial and may determine when synaptic changes may occur after the appropriate stimulation. To further analyze this point, it will be interesting to investigate whether disturbance of the temporal restriction of arg 3.1/arc expression, for example, by overexpression and gene ablation, interferes with learning and memory.

\section{Functional Implications}

Like other IEGs, arg 3.1/arc may be expressed $15 \mathrm{~min}$ after our paradigm, in response to the sensory stimulation, motor activity, and/or stress (Tischmeyer and Grimm 1999), which would explain the general time effect detected in some brain areas of all groups, resulting from an elevated arg 3.1/arc mRNA expression 15 min compared with $4.5 \mathrm{~h}$ after the test. In contrast, the learning groupspecific peak of arg 3.1/arc expression at the 15-min time point in the granule cell layer of the olfactory bulb, the anterior cingulate cortex, and the layers I-IV and VI of the parietal cortex is likely to reflect changes related to the acquisition of the task. Possibly, central modulatory afferents in combination with sensory inputs may alter arg 3.1/ arc expression in a situation of learning (Stork and Welzl 1999). Supportingly, IEG expression in the mammalian brain is highly dependent on activation of the noradrenergic system (Cirelli et al. 1996), and expression of the IEG c-fos in granule cells of the olfactory bulb depends on both sensory and centrifugal afferents (Sallaz and Jourdan 1996). In addition, odor-

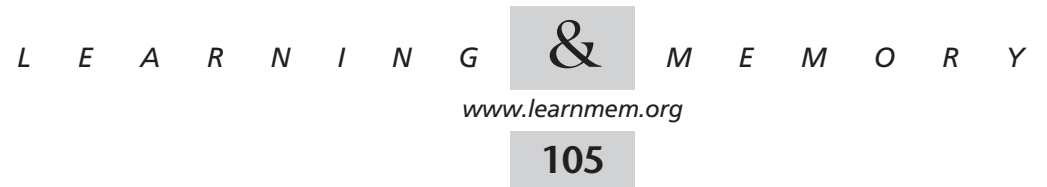


induced arg 3.1/arc mRNA expression in the granule cell layer of the olfactory bulb depends on the novelty of the stimulus, which is known to involve centrifugal afferent inputs (Montag-Sallaz and Buonviso 2002). Therefore, the coincidence of both sensory and centrifugal inputs may be important for the expression of arg 3.1/arc in particular brain areas 15 min post-trial. The late peak of arg 3.1/arc expression in the anterior and posterior cingulate cortex, the piriform cortex, the hippocampus (CA1-CA3, dentate gyrus), the amygdala, and all layers of the parietal, sensory, and motor cortices indicates that these brain areas participate in the formation of the memory trace $4.5 \mathrm{~h}$ after the learning paradigm. These results are in agreement with the more general theory that memory consolidation involves interactions among neuronal systems as well as cellular changes within specific systems (McGaugh 2000).

\section{Conclusion}

Using a one-trial learning paradigm in this study, we demonstrated that learning itself is sufficient to induce a specific temporal pattern of arg 3.1/arc up-regulation in several limbic and cortical areas of the mouse brain. Furthermore, the two waves of learning-induced arg 3.1/arc expression temporally correspond to the two mRNA and protein synthesisdependent phases required for long-term memory formation.

\section{METHODS}

\section{Animals}

Male C57BL/6 mice (Charles River Laboratories) were housed individually under standard laboratory conditions $(12 \mathrm{~h} ; 12 \mathrm{~h} /$ light:dark cycle with light on at $06: 00 ; 21 \pm 2^{\circ} \mathrm{C}$ room temperature) and had free access to food and water. Animals were distributed randomly in three experimental groups as follows: a learning group (L; $n=14$ ), a control group (C; $n=15)$, and a retrieval group (R; $n=10$ ). The animals were sacrificed at different time points. A total of 15 mice (L, $n=4 ; \mathrm{C}, n=6 ; \mathrm{R}, n=5$ ) were sacrificed $15 \mathrm{~min}, 5$ mice (L, $n=3 ; \mathrm{C}, n=2) 1 \mathrm{~h}, 15$ mice (L, $n=5 ; \mathrm{C}, n=5 ; \mathrm{R}, n=5$ ) $4.5 \mathrm{~h}$, and 4 mice (L, $n=2 ; \mathrm{C}, n=2$ ) $6 \mathrm{~h}$ after the test. All brains were processed for nonradioactive in situ hybridization. In addition, the brains from animals sacrificed at the 15-min and 4.5-h time point were processed for radioactive in situ hybridization.

\section{Light/Dark Box Behavioral Paradigm}

The light/dark box was a rectangular gray plastic arena with a dark $(12.5 \times 25 \mathrm{~cm})$ and an illuminated $(25 \times 25 \mathrm{~cm}, 250$ lux $)$ compartment separated by a wall with a $5 \times 5-\mathrm{cm}$ opening (Stork et al 1999). For all experimental days, the mice were adapted to the experimental room for $1 \mathrm{~h}$ prior to the test. During the first $3 \mathrm{~d}$, the animals were placed in the middle of the illuminated compartment and allowed to explore this compartment for $10 \mathrm{~min}$, but had no access to the dark compartment. On day 4 , the access to the dark compartment was opened for the learning and retrieval animals, but not for the control group. Learning and control animals were sacrificed $15 \mathrm{~min}, 1 \mathrm{~h}, 4.5 \mathrm{~h}$, or $6 \mathrm{~h}$ after the end of the 10-min test. On day 5, the retrieval animals were submitted to the same test with free access to the dark compartment, and sacrificed 15 min or $4.5 \mathrm{~h}$ after the end of the test. The behavior of the animals in the light/dark box was videotaped, and the latency to enter the dark compartment was measured on day 4 for the learning and on days 4 and 5 for the retrieval groups.

\section{In Situ Hybridization}

Levels of arg 3.1/arc mRNA were examined in tissue sections by use of in situ hybridization of digoxigenin- and ${ }^{35}$ S-labeled antisense cRNA probes. Sense and antisense arg 3.1/arc probes were generated as described (Montag-Sallaz et al. 1999).

Brain tissue was processed for in situ hybridization as described previously (Montag-Sallaz et al. 1999). Briefly, brains were removed and quickly frozen by immersion in isopentane $\left(-40^{\circ} \mathrm{C}\right)$. Frontal sections $\left(14-\mu \mathrm{m}\right.$ thick) were cut in a cryostat at $-15^{\circ} \mathrm{C}$ and collected on silane-coated glass slides. After fixation in $4 \%$ paraformaldehyde in phosphate-buffered saline (PBS; $\mathrm{pH} 7.2$ ), sections were prehybridized for $3 \mathrm{~h}$ at $37^{\circ} \mathrm{C}$ in prehybridization buffer containing 50\% formamide, $25 \mathrm{mM}$ EDTA, $50 \mathrm{mM}$ Tris- $\mathrm{HCl}$ ( $\mathrm{pH} 7.5$ ), $2.5 \times$ Denhardts solution, $0.25 \mathrm{mg} / \mathrm{mL}$ tRNA (Roche), and $20 \mathrm{mM}$ $\mathrm{NaCl}$. Sections were incubated for $12-15 \mathrm{~h}$ at $55^{\circ} \mathrm{C}$ with the probe at the concentration yielding maximal sensitivity of the antisense probe in hybridization buffer [50\% formamide, $20 \mathrm{mM}$ Tris- $\mathrm{HCl}(\mathrm{pH}$ 7.5), $1 \mathrm{mM}$ EDTA, $1 \times$ Denhardts solution, $0.5 \mathrm{mg} / \mathrm{mL}$ tRNA, 0.1 $\mathrm{mg} / \mathrm{mL}$ poly(A) (Sigma), $0.1 \mathrm{M}$ dithiothreitol (DTT; Sigma), 10\% dextran sulphate (Sigma)]. After hybridization, sections were rinsed twice for $30 \mathrm{~min}$ in $0.2 \times \mathrm{SSC}(30 \mathrm{mM} \mathrm{NaCl}, 3 \mathrm{mM}$ sodium citrate at $\mathrm{pH} 7.4$ ) and three times for $90 \mathrm{~min}$ in $0.2 \times \mathrm{SSC}-50 \%$ formamide at $55^{\circ} \mathrm{C}$. Then, the sections were washed at room temperature with $0.2 \times$ SSC. For the ${ }^{35} \mathrm{~S}$ labeled probes, sections were dehydrated in ascending concentrations of ethanol, and air dried before exposure to $\beta$-max hyperfilms (Kodak) for $5 \mathrm{~d}$ at $4^{\circ} \mathrm{C}$. For the digoxigeninlabeled probes, sections were equilibrated with buffer $1(100 \mathrm{mM}$ Tris-HCl, $150 \mathrm{mM} \mathrm{NaCl}$ at $\mathrm{pH} 7.5$ ) for $10 \mathrm{~min}$, followed by blocking for $30 \mathrm{~min}$ in buffer 2 [1\% Boehringer blocking reagent in buffer 1 , modified by addition of $0.5 \%$ BSA fraction V (Sigma)], and incubated overnight at $4{ }^{\circ} \mathrm{C}$ with alkaline phosphatase-conjugated antidigoxigenin Fab fragments (Roche) at a dilution of 1:500 in buffer 2. Sections were then washed twice for $15 \mathrm{~min}$ in buffer 1 , equilibrated for $5 \mathrm{~min}$ in buffer 3 (100 mM Tris-HCl, $100 \mathrm{mM} \mathrm{NaCl}, 50$ $\mathrm{mM} \mathrm{MgCl}_{2}$ at $\mathrm{pH}$ 9.5) and developed for several hours in the dark with buffer 3 containing $0.34 \mathrm{mg} / \mathrm{mL}$ 4-nitroblue tetrazolium chloride (NBT; Roche), $0.175 \mathrm{mg} / \mathrm{mL}$ 5-bromo-4-chloro-3-indolylphosphate (BCIP; Roche), and $0.25 \mathrm{mg} / \mathrm{mL}$ levamisole (Sigma). The development of the reaction was stopped by washing with buffer 4 (10 mM Tris-HCl, $1 \mathrm{mM}$ EDTA at pH 8.0), after which sections were mounted in Fluoromount. At the same concentration as the antisense probes, sense probes $\left({ }^{35} \mathrm{~S}\right.$ - or digoxigenin-labeled) did not provide any significant labeling (data not shown).

\section{Data Analysis}

Sections taken from each brain were $4,28 \mathrm{~mm}$ (olfactory bulb areas) and $0,74-0,62 \mathrm{~mm}$ anterior to the bregma (anterior cingulate cortex, piriform, sensory, and motor cortices) and 1,70-1,94 $\mathrm{mm}$ posterior to the bregma (posterior cingulate cortex, hippocampus, parietal cortex, amygdala). Divisions between brain regions followed Franklin and Paxinos (1997).

The nonradioactive in situ hybridization using digoxigeninlabeled antisense arg 3.1/arc probe provides a resolution at the cellular level. Therefore, the density of labeled cells could be evaluated by visual examination of the sections using an Axioskop microscope (Zeiss). This first study allowed the precise determination of the brain areas in which arg 3.1/arc mRNA expression levels are

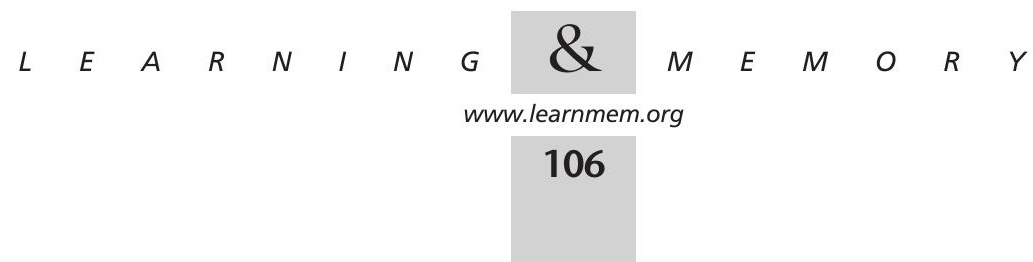


altered after performance of the task and of the time points when these changes occur. The radioactive in situ hybridization using ${ }^{35}$ S-labeled antisense arg 3.1/arc probe does not provide a cellular resolution, but is a more sensitive method, better suited for precise quantification. The densitometric analysis of film autoradiograms was carried out using the public domain NIH Image program (developed at the U.S. National Institutes of Health and available on the Internet at http://rsb.info.nih.gov/nih-image/). Uncalibrated optical densities were evaluated for those brain areas undergoing expression changes as identified by in situ hybridization of digoxigeninlabeled antisense arg 3.1/arc probe. These uncalibrated optical densities were corrected using as reference the optical density of a control area (central part of the olfactory bulb, corpus callosum) to eliminate variations due to external factors like film background. The relative optical densities obtained for each brain area could then be compared between the different animal groups (Pinaud et al. 2001; Montag-Sallaz and Buonviso 2002). Determination of the density of labeled cells and densitometric analysis of film autoradiograms were carried out by an experimenter not aware of the experimental treatment of the animals

\section{Statistics}

Performance of the animals and differences in arg 3.1/arc expression between groups were analyzed statistically using a 1-way analysis of variance (ANOVA; Statview, SAS Institute Inc.) with test day as a factor. A 2-way analysis of variance with time of sacrifice after the test ( $15 \mathrm{~min}$ and $4.5 \mathrm{~h}$ ) and stimulation (control, learning, and retrieval) as factors was performed to statistically analyze arg 3.1/ arc mRNA expression detected by the ${ }^{35}$ S-labeled antisense arg $3.1 /$ arc probe. The $\mathrm{F}$ value corresponds to the variance ratio (variance between the group means/average variance of the values within individual groups). Comparisons of means were used as post-hoc test (Fisher, Bonferroni/Dunn). A $P$-value smaller than $0.05(P<0.05)$ was considered significant.

The publication costs of this article were defrayed in part by payment of page charges. This article must therefore be hereby marked "advertisement" in accordance with 18 USC section 1734 solely to indicate this fact.

\section{ACKNOWLEDGMENTS}

The authors are grateful to Karla Sowa for excellent technical help for the handling of the mice.

\section{REFERENCES}

Cirelli, C., Pompeiano, M., and Tononi, G. 1996. Neuronal gene expression in the waking state: A role for the Locus Coeruleus. Science 274: 1211-1215.

DiAntonio, A. 2000. Translating activity into plasticity. Nature 405: 1011-1012.

Franklin, K.B.J and Paxinos, G. 1997. The mouse brain in stereotaxic coordinates. Academic Press, Inc., San Diego, CA.

Guthrie, K., Rayhanabad, J., Kuhl, D., and Gall, C. 2000. Odors regulate Arc expression in neuronal ensembles engaged in odor processing. NeuroReport 11: 1809-1813.

Guzowski, J.F., McNaughton, B.L., Barnes, C.A., and Worley, P. 1999 Environment-specific expression of the immediate-early gene Arc in hippocampal neuronal ensembles. Nat. Neurosci. 2: 1120-1124.

Guzowski, J.F., Lyford, G.L., Stevenson, G.D., Houston, F.P., Mc Gaugh, J.L., Worley, P.F., and Barnes, C.A. 2000. Inhibition of activity-dependent Arc protein expression in the rat hippocampus impairs the maintenance of long-term potentiation and the consolidation of long-term memory. J. Neurosci. 20: 3993-4001.
Guzowski, J.F., Setlow, B., Wagner, E., and Mc Gaugh, J.L. 2001 Experience-dependent gene expression in the rat hippocampus after spatial learning: A comparison of the Immediate-early genes Arc, c-fos, and zif268. J. Neurosci. 21: 5089-5098.

Huntley, G.W., Benson, D.L., and Colman, D.R. 2002. Structural remodeling of the synapse in response to physiological activity. Cell 108: 1-4

Igaz, L.M., Vianna, M.R.M., Medina, J.H., and Izquierdo, I. 2002. Two time periods of hippocampal mRNA synthesis are required for memory consolidation of fear-motivated learning. J. Neurosci. 22: 6781-6789.

Kelly, M.P. and Deadwyler, A. 2002. Acquisition of a novel behavior induces higher levels of arc mRNA than does overtrained performance. Neuroscience 110: 617-626.

Link, W., Konietzko, U., Kauselmann, G., Krug, M., Schwanke, B., Frey, U., and Kuhl, D. 1995. Somatodendritic expression of an immediate-early gene is regulated by synaptic activity. Proc. Natl. Acad. Sci. 92: $5734-5738$

Lyford, G., Yamagata, K., Kaufmann, W., Barnes, C., Sanders, L., Copeland, N., Gilbert, D., Jenkins, N., Lanahan, A., and Worley, P. 1995. Arc, a growth factor and activity-regulated gene, encodes a novel cytoskeleton-associated protein that is enriched in neuronal dendrites. Neuron 14: 433-445.

Matus, A. 2000. Actin-based plasticity in dendritic spines. Science 290: $754-758$.

Mc Gaugh, J.L. 2000. Memory-A century of consolidation. Science 287: 248-251.

Montag-Sallaz, M. and Buonviso, N. 2002. Altered odor-induced expression of $c$-fos and $\arg 3.1$ immediate early genes in the olfactory system after familiarization with an odor. J. Neurobiol. 52: 61-72.

Montag-Sallaz, M., Welzl, H., Kuhl, D., Montag, D., and Schachner, M. 1999. Novelty-induced increased expression of the immediate early genes $c$-fos and $\arg 3.1$ in the mouse brain. J. Neurobiol. 38: 234-246.

Pinaud, R., Penner, M.R., Robertson, H.A., and Currie, R.W. 2001. Upregulation of the immediate early gene arc in the brains of rats exposed to environmental enrichment: Implications for molecular plasticity. Mol. Brain Res. 91: 50-56.

Quevedo, J., Vianna, M.R.M., Roesler, R., de-Paris, F., Izquierdo, I., and Rose, S.P.R. 1999. Two time windows of anisomycin-induced amnesia for inhibitory avoidance training in rats: Protection from amnesia by pretraining but not pre-exposure to the task apparatus. Learn. Mem. 6: 600-607.

Sallaz, M. and Jourdan, F. 1996. Odor-induced c-fos expression in the rat olfactory bulb: Involvment of centrifugal afferents. Brain Res. 721: 66-75

Schuman, E.M. 1999. mRNA trafficking and local protein synthesis at the synapse. Neuron 23: 645-648.

Steward, O. and Schuman, E.M. 2001. Protein synthesis at synaptic sites on dendrites. Annu. Rev. Neurosci. 24: 299-325.

Steward, O. and Worley, P.F. 2001. A cellular mechanism for targeting newly synthesized mRNAs to synaptic sites on dendrites. Proc. Natl. Acad. Sci. 98: 7062-7068.

Steward, O., Wallace, C.S., Lyford, G., and Worley, P.F. 1998. Synaptic activation causes the mRNA for the IEG Arc to localize selectively near activated postsynaptic sites on dendrites. Neuron 21: 741-751.

Stork, O. and Welzl, H. 1999. Memory formation and the regulation of gene expression. Cell. Mol. Life Sci. 55: 575-592.

Stork, O., Welzl, H., Wotjak, C.T., Hoyer, D., Delling, M., Cremer, H., and Schachner, M. 1999. Anxiety and increased 5-HT1A receptor response in NCAM null mutant mice. J. Neurobiol. 40: 343-355.

Tischmeyer, W. and Grimm, R. 1999. Activation of immediate-early genes and memory formation. Cell. Mol. Life Sci. 55: 564-574.

Tiunova, A., Anokhin, K., and Rose, S.P.R. 1998. Two critical periods of protein and glycoprotein synthesis in memory consolidation for visual categorization learning in chicks. Learn. Mem. 4: 401-410.

Wallace, C.S., Lyford, G., Worley, P.F., and Steward, O. 1998. Differential intracellular sorting of IEG mRNAs depends on signals in the mRNA sequence. J. Neurosci. 18: 26-35.

Wells, D.G., Richter, J.D., and Fallon, J.R. 2000. Molecular mechanisms for activity-regulated protein synthesis in the synapto-dendritic compartment. Curr. Opin. Neurobiol. 10: 132-137.

Received July 15, 2002; accepted in revised form January 3, 2003

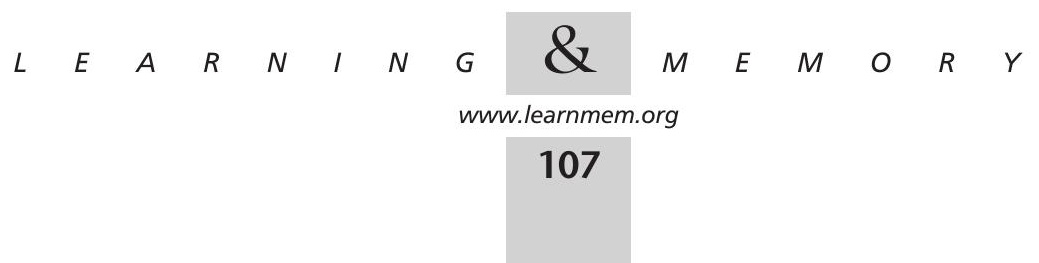




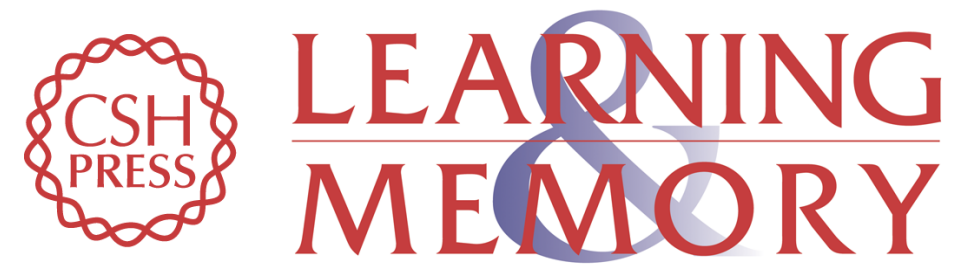

\section{Learning-Induced arg 3.1/arc mRNA Expression in the Mouse Brain}

Monique Montag-Sallaz and Dirk Montag

Learn. Mem. 2003, 10:

Access the most recent version at doi:10.1101/lm.53403

References This article cites 28 articles, 11 of which can be accessed free at: http://learnmem.cshlp.org/content/10/2/99.full.html\#ref-list-1

License

Email Alerting Receive free email alerts when new articles cite this article - sign up in the box at the Service top right corner of the article or click here. 